\title{
Scholarship as a Corporate Philanthropy, "A Half Blood Philanthropy" Strategy to Sustain
}

\author{
Yoremia Lestari Ginting*, Fibriyani Nur Khairin, Anisa Kusumawardani, Iskandar \\ Department of Accounting, Mulawarman University, Samarinda-East Kalimantan, Indonesia
}

Copyright $\mathrm{C} 2019$ by authors, all rights reserved. Authors agree that this article remains permanently open access under the terms of the Creative Commons Attribution License 4.0 International License

\begin{abstract}
Corporate Social Responsibility (CSR) is a concept that continues to grow yet does not own approved definition or a set of specific criteria fully recognized by parties involved in it. This study aimed to reveal the meaning of Scholarship as corporate philanthropy, which is part of the CSR program. Qualitative case study method with interpretive paradigms was used to find the meaning of "philanthropy". Data was collected from PKT sustainability report and interview sessions with program manager and scholarship recipients. This study revealed that the corporate philanthropy is "half-blood philanthropy" because they interpret the provision of scholarship as social expenditure and not as social investment.
\end{abstract}

Keywords Interpretive, Philanthropy, Qualitative Case Study, Sustainability Report

\section{Introduction}

A business' products or services certainly play big roles in company success, but without a positive public perception, there will not be enough interest for them to grow. The role of corporate social responsibility (CSR) is extremely important because positive relationship with stakeholders that emit high ethical standards and charitable nature is likely to increase long-term profits, compared to a business lacking in CSR. Reference [1] suggests that investing time and other resources in addressing stakeholders' interests is a rational managerial activity. Today, corporate face the task of balancing the competing interests of many stakeholders for the long- term survival of the firm [2].

Corporate Philanthropy is a direct contribution by a corporation to a charity or cause, most often in the form of cash grants, donations and or in kind services [3]. The most visible element of a company's CSR activities is often its charitable giving, which in most cases could very easily be decoupled from its product [4]. Many companies provide support to schools through donation of infrastructure and learning material and a similar proportion provide scholarships in cash and/or kind [5]. Community investment initiatives are perhaps the most well-known aspects of CSR in an Asia specific context with its rich history of philanthropy [6] [28].

As a company whose existence is inseparable from the role of society and the environment, PKT is committed to synergize the resources of the company, the community and government to create harmony. Implementation of CSR by PKT is a form of implementation of the Minister of SOE Regulation No. Per-05 / MBU / 2007 as revised by No. Per-08 / MBU / 2013 on the SOE Partnership Program with Small Business and the Social Development Program. The pillars of PKT's CSR programs are Human Capital Development, Strengthening the Economy, Synergy Development and Partnership, Strengthening Organizational Governance, Sustainable Environmental Management and Improvement of Public Communication.

The CSR programs are conducted through the Community Development Department (CDD) programs, certain initiatives under the Department of Public Relations. One of the programs is to provide educational assistance through scholarships, which is the focus of this study. PKT's concern for education is manifested through a program that provides opportunities for high school students and equivalents in Bontang and East Kalimantan to gain a full scholarship to continue their study at leading universities nationwide. The entire cost of education and living expenses is borne by the company from the beginning until the end of study. Other program is Amil Zakat Institution (LAZ) PKT Scholarship that has the same goal, although in a different mechanism.

Reference [7] shows that corporations can use their charitable efforts to improve their competitive context the quality of the business environment in the location or locations where they operate. Using philanthropy to enhance context brings social and economic goals into alignment and improves a company's long-term business prospects. Therefore, this study sought to reveal the 
meaning of Scholarship Award as corporate philanthropy, which is part of the CSR program.

\section{Methodology}

This research used qualitative case study method with interpretive paradigm $[8,9,10]$. Qualitative case study is an approach that facilitates exploration of a phenomenon within its context using a variety of data sources [11] [29]. This ensures that the issue is not explored through one lens, but rather a variety of lenses which allow for multiple facets of the phenomenon to be revealed and understood. Meanwhile, interpretive paradigm used to understand the phenomenon of corporate philanthropy by the company as part of CSR, the meaning of charity actions by the company and the impact of such action.

This research took place in one of manufacturing companies in East Kalimantan. Results of business activities of these companies may negatively affect the environment and society around the company. Thus, the company ran the CSR program as a way to minimize negative impacts on the environment and society. This study focused only on the scholarship program provided by the company to the local community particularly to students-in-need and students with distinctive achievement. Data was collected from PKT Sustainability Report (SR) and interviews. Interview session was held with the Community Development Department (CDD) from PKT and some of scholarship recipients. Snowball sampling method was used to collect sample of scholarship recipients. Data obtained through SR-related scholarship program and interviews with informants will be interpreted to derive meaning from the company's corporate philanthropy as implementing CSR programs and student scholarships as a representative of the stakeholders.

\section{Results}

\subsection{Overview of Corporate Philanthropy in Sustainability Report}

The role of society is indispensable for the existence, continuity and development of a corporation. As an integral part of society, company needs to be committed to make an impact for people with interests in the company, both internally and externally. The form of the company's commitment towards society and environment is embodied in activities of Corporate Social Responsibility (CSR).

However, Indonesia does not yet have a clear concept regarding implementation of corporate responsibility, so companies have their own interpretation to the concept in accordance to their interests, such as in the form of donations to the community around the company, scholarships, and community empowerment programs. Reference [3] said that corporate social responsibility is a commitment to improve community well-being through discretionary business practices and contribution of corporate resources.

Disclosure of company's CSR activities can be presented in the Annual Report and / or Sustainability Report (SR). In Indonesia separate report on CSR is still a voluntary disclosure. PKT is one of the manufacturing companies that do both type of reporting. However, a more detailed explanation of strategies and programs on CSR is more reflected in the SR, and it is the reason of this research focused on the SR of PKT.

Sustainability report provides information about organizations' impact of natural resources, employees and the community. This information may assist stakeholders in assessing organizations' long-term creation of value beyond the products and services they provide and the profit they generate [12] [30].

In PKT's sustainability report [13] related to costs associated with the community, there was educational assistance provided to local communities. The development of local human resources is a major concern of the company, both for people and environment. Educational scholarships given are one of the flagship programs in the field of CSR that are awarded to outstanding students from poor families. Through this program, students are able to obtain fund needed to continue their education at leading universities in Indonesia. Scholarships awarded covers tuition and living expenses in accordance with its specified budget.

Total expenses incurred by the company for scholarships increases every year and during $2014 \mathrm{Rp} 3.13$ billion was given from the total amount of Rp 6.27 billion CSR fund. Based on data from the SR issued by the PKT, it was apparent that the amount of both budget and realization fluctuate each year. Aside from that, scholarships always take the biggest portion of CSR fund. However, charity provided in form of scholarships was still limited to conventional scholarship program, which still focused on the academic achievement of the recipients. There was no special intervention program done by the company to increase academic achievement of recipients, all left entirely to the universities and the recipient themselves. Furthermore, the assistance provided was in the form of aid learning tools, tuition fees and living cost. This led the company to recognize the costs incurred related to scholarships as social expenditures, whereas a CSR is supposed to be a social investment and not merely expenditure. So the impact on the company recognizes the costs incurred related to scholarships are just as social expenditures, whereas the fee is basically a part of the social investment [14]. This explanation will be presented more clearly in the next section along with data from interviews. 


\subsection{Scholarship in Corporate Philanthropy: Corporate' and Stakeholders' Views}

Companies have the opportunity to be one of the key liaisons needed by society in terms of education because they have the resources and political influences required to improve educational outcomes which will in turn help them to nurture local talents. Leading businesses are already devising corporate social responsibility (CSR) programs that are actively supporting education.

CSR program for education so far only implemented in form of scholarships for students in need with distinctive achievement and helping to repairing school learning tools. And strangely it became pride by company is considered to have a lot of help. CCD of PKT as a scholarship provider reveals:

"The recipients of our scholarships are elected students and we filtered through several stages"

From our interview with the program manager, we could see that there was a sense of pride from the company as the provider because they felt that they had been able to help local communities through scholarships.

The 'conventional' scholarship program, although limited only to providing tuition assistance, has been quite helpful. However, if we see the problem of education nationwide, scholarship program in general cannot be considered as an innovative solution. This happened because company considered the cost of scholarships issued only as social expenditure and not as social investment. One respondent expressed the issues clearly:

"The need for guidance or a meeting between the company with the scholarship awardees, especially in terms of learning and living in another city"

One reason is that the company providing scholarships generally did not deal with the efforts to equip and instill important values and skills needed by the students. On the other hand, those important values and skills failed to be obtained either from families or schools. One proof is the phenomenon that we see today, hundreds of thousands of college graduates, even from leading universities, did not have the skills and independence to gain successful career in the midst of society.

As expressed by one of the students who were awarded the scholarships: "I am still looking for a job. Even though I got scholarships from PKT if I want to work there I will have to apply just like any other applicants, there is no guarantee".

If the company believed that the cost incurred was a social investment, it should be innovative about how to conduct philanthropy when it has a variety of "pieces" to put together. Just cash or just volunteer time or just inkind/product donations do not lead to innovation or creative uses of company resources to solve community problems. Company need to develop more innovative scholarship program. As the expectations of a respondent: "In the future, the company need to conduct training programs on a regular basis to the protege (red: awardees) also need existing alumni associations so that it can build solidarity between awardees, and may help each other in term of job opportunities".

\section{Discussion}

\subsection{Sustainability Reporting: Transforming from a "Trust Me" to a "Tell Me"}

Many companies are increasingly aligning their social investment strategies with their business strategies, which can bring indirect benefits to the business such as improved reputation. In recent years, global challenges in social and environmental have generated pressures on companies to disclosing how they are utilizing, developing (or depleting) and, more generally, affecting human capital and natural resources [15]. In doing so, transparency and dialogue can help to make a business appear more trustworthy, and push up the standards of other organizations at the same time [16].

In $2014 \mathrm{KPMG}$ presents research into reporting of social investment by 100 of the world's largest companies and their associated foundations [17]. The results showed that companies focus on measuring and reporting inputs to social programs but that reporting on the impacts of social investment was far less common.

Most companies used to disclose 'limited' information of their social and environmental activities in their annual reports. Unfortunately, the information seems not sufficient to satisfy all stakeholder expectations. To bridge the expectation gap, PKT launched its stand-alone corporate sustainability report and intended to substitute annual Report. Without sustainability report, the firm risks losing the most important communication means it have for sharing information about its programs directed toward people in surrounding location.

At this time, financial condition is not enough to guarantee sustainable corporate value, this is due to demands from stakeholders that not only want to know more than just a company's financial performance, but also want to know about non-financial performance such as environmental and social impacts [18].

Sustainability is a balance between people-planet- profit, known as the concept of the Triple Bottom Line (TBL), and is determined by positive or negative impacts it has to the economic, social and environmental condition [19]. Thus, the necessity of Sustainability reporting containing information regarding financial and non- financial performance consists of social and environmental activities that put more emphasis on the principles and standards of disclosure able to reflect company's overall activity level and in the end enabling the company to grow continuously [20].

The issuance of government regulations in the Company Law No.40/2007 was also the basis for the company to 
conduct and report its CSR activities. Even so, the actual implementation of CSR by companies has been done long before the regulation, but in the report they do not clearly explain the social costs incurred or the CSR category. So the execution was limited to "trust- me" that they have been doing CSR activities even though not reported in the reporting on CSR explanation.

The increasing trend of sustainability report is also accompanied by rising guidelines or rules provided by government agencies and industrial bodies [21]. One of the manuals used is GRI (Global Reporting Initiative). Many foreign companies follow the standards and framework provided by GRI for reporting sustainability.

PKT is one of the companies that compiles the SR by using the guidelines of the GRI. The company is also a member of National Center for Sustainability Reporting (NCSR) and has repeatedly won awards in Indonesia Sustainability Reporting Award (ISRA) event from various fields every year. SR became a tool for the company "to tell" the charitable activities. It was doing to stakeholders and of course this will have an impact on the company. So it can be said that company reporting company is also an attempt to maintain its legitimacy Reference [22] stated that in particular, cash donations can signal financial strength. A substantial and unexpected increase in amount of cash donations can signal that a firm's insiders perceive the company's future to be good enough to spend ultra-discretionary funds on unrelated third parties. Then it also transforms the corporate philanthropy (i.e., companies engage in pro- social sacrifices because stakeholders are willing to pay more for corporate goodness) to a signaling explanation (i.e., pro-social sacrifices mitigate asymmetric information about a firm's fundamentals).

Sustainability reporting promotes transparency which will improve company's image and stakeholders' confidence of the company so that stakeholders including investors will continue to maintain good relations with the company [23]. Investors increasingly have the desire to invest in companies that conduct practices related to social and environmental good. Companies and investors discovered that investing in applying the principles of sustainability have the capacity to create value in the long term [24]. This shows that sustainability reporting will continue to rise.

\subsection{Half-Blood Philanthropy Strategy}

Practice of CSR would suggest six core characteristics, which are: (1) CSR focuses on voluntary activities of business; (2) CSR is concerned with internalizing or managing externalities; (3) CSR has a multiple stakeholder orientation; (4) CSR attempts an alignment of societal, environmental and economic responsibilities; (5) CSR emerges with a fairly common set of practices and values; and (6) CSR goes beyond mere philanthropy [25].

Companies face dilemmas in philanthropy. One of the key dilemmas in corporate philanthropy is how to engage their stakeholders, but also make sure the CSR program they held is connect to company concerns or strategies. Reference [7] shows many companies seek to be more strategic in their philanthropy but what passes for "strategic philanthropy" today is almost never truly strategic, and often it is not even particularly effective as philanthropy. Increasingly, philanthropy is used as a form of public relations or advertising, promoting a company's image or brand through cause-related marketing or other high-profile sponsorships. In fact, most corporate giving programs have nothing to do with a company's strategy. They are primarily aimed at generating positive publicity but the majority of corporate contribution programs are diffuse and unfocused. Most consist of numerous small cash donations given to aid local civic causes or provide general operating support to universities and national charities. This "half-blood" strategy, rather than being tied to well-thought-out social or business objectives, the contributions often reflect the personal beliefs and values of executives or employees.

Corporations can use their charitable efforts to improve their competitive context - the quality of the business environment in the location or locations where they operate. Using philanthropy to enhance context brings social and economic goals into alignment and improves a company's long-term business prospects. In addition, addressing context enables a company not only to give money but also to leverage its capabilities and relationships in support of charitable causes. In the long run, then, social and economic goals are not inherently conflicting but integrally connected [7].

The social benefit to society is an improved educational system and better employment opportunities for low-income local citizens. The economic benefit is greater availability of specially trained graduates. In long- term the impact of an education program could be increase in employment rates and reduced poverty as a result of better early year's education.

Then, the "half-blood philanthropy" strategy also makes corporate to understand the link between philanthropy and competitive context. It helps companies identify where they should focus their corporate giving and how they can achieve the greatest social and economic impact through their contributions [7].The "where" and the "how" are mutually reinforcing. By focusing on the contextual conditions most important to their industries and strategies, companies ensure that their corporate capabilities will be particularly well suited to helping grantees create greater value. It does not just address a company's self-interest, it benefits many through broad social change. If a company's philanthropy only increases its reputation, after all, it would not qualify as a charitable deduction.

Whatever the company reason or motive for doing CSR, it is certainly important. As stated previously that CSR is a future savings for the company to earn a profit. The 
advantage gained is not only economic benefits, but also it is more than social and natural environment benefit for the company's sustainability.

\section{Conclusions}

Some may think that philanthropy is a nuisance for a company and will reduce its profit. However, such assumption is not appropriate. Charitable programs will raise a company's image in the presence of the stakeholders and the reputation will be somehow leveraged. It is not easy to carry out appropriate CSR programs. It takes a good cooperation between companies, communities, and stakeholders. Also, the paradigm of corporate philanthropy merely as a cost should be shifted into an investment.

In line with what was expressed [26], there are three key points about the nature of CSR [27]. First, CSR is an act of love for the neighbor in an effort to realize the vision or hope to become a better company so that it can grow and develop in a sustainable manner. Secondly, CSR is the sacrifice of economic resources (assets) and non- economic (efforts) to love and loving others that must be carried out in sincere, wholehearted and continuous manner. Third, all the sacrifices to carry out CSR is a strategic investment.

Results of this study contributed in providing feedback for company to develop a scholarship program based on the concept of CSR as a social investment. The better the philanthropy program is given to the public, the better the company's sustainability become. We are eager to see company develop from giving "half-blood philanthropy" toward "pure-blood philanthropy". For further research, results of this study can be used as the basis for developing a model of corporate philanthropy, which are more appropriate to the environment and local communities.

\section{REFERENCES}

[1] R. E. Freeman, K. Martin, and B. Parmar, "Stakeholder capitalism," Journal of Business Ethics, 74, 303-14, Berlin: Springer, 2007

[2] L. O'Riordan, and J. Fairbrass, "Managing CSR stakeholder engagement: a new conceptual framework," Journal of Business Ethics, 125, 121-145, Berlin: Springer, 2014.

[3] P. Kotler, and N. Lee, Corporate Social Responsibility: Doing the Most Good for Your Company and Your Cause. Hoboken, New Jersey: John Wiley \& Sons, Inc., 2005

[4] R. Caldwell, "The real economics of corporate social responsibility," Retail Market Insider, 2006, available online at

http://www.ihsglobalinsight.com/gcpath/retailmarket_april .htm (accessed on January 28, 2016)
[5] A. Parekh, and P. Prakash, "Why companies prefer CSR in education", available online at http://www.thehindubusines sline.com/opinion/why-companies-prefer-csr-in-education/ article7040552.ece. Published on March 27, 2015 (accessed on January 28, 2016).

[6] CSR Asia Business Barometer, The State of CSR Disclosure in Asia 2008, October 2008.

[7] M. E. Porter, and M. R. Kramer, "The competitive advantage of corporate philanthropy," Harvard Business Review, 2002, available online at https://hbr.org/2002/12/th e-competitive-advantage-of-corporate-philanthropy (accessed on January 25, 2016).

[8] Djunaidi, H. M. Ghony, and A. Fauzan, "Qualitative research methodology" (in Indonesia), Metodologi penelitian kualitatif, Ar-Ruzz Media, Jogjakarta, 2012.

[9] N. Indriantoro, and B. Supomo, "Business research methodology for accounting and management" (in Indonesia), Metodologi Penelitian Bisnis Untuk Akuntansi dan Manajemen, Yogyakarta: BPFE, 2013.

[10] Shi, W., \& Qu, P. A Comparative Study on Chinese and English Compliments from the Perspective of Intercultural Communication. International Journal of English Language and Literature Studies, 7(4), 133-137, 2018.

[11] Al Zoubi, S. M. The Significance of Error Analysis in Written Production: A Case Study of Ajloun National University Students. International Journal of English Language and Literature Studies, 7(4), 150-159, 2018.

[12] M. L. James, “Accounting majors' perception of advantages and disadvantages of sustainability and integrated reporting," Journal of Legal, Ethical and Regulatory Issues, vol. 18 , no. $2,2015$.

[13] PT.Pupuk Kaltim, "Progressing in building a sustainable business" (in Indonesia), Melangkah maju membangun bisnis yang berkelanjutan, Sustainability Reporting, 2014.

[14] M. A. Zaelani, "CSR programs in education as a social investment" (in Indonesia), Program CSR bidang pendidikan sebagai investasi sosial, available online at http://www.kompasiana.com/zaelani_ma/program-csrbidang-pendidikan-sebagai-investasisosial 5520e90f8133116c7419fd12, 2015 (accessed on January 28, 2016).

[15] I. Ioannou, and G. Serafeim, "The consequences of mandatory corporate sustainability reporting: evidence from four countries," Working Paper, 11-100, Harvard Business School, August 20, 2014.

[16] R. Fisman, G. Heal, and V. B. Nair, "A model of corporate philanthropy," Working paper, Wharton School, University of Pennsylvania, 2006.

[17] KPMG International, "Unlocking the value of social investment," KPMG International Sustainable Insight, 2014.

[18] A.H.N. Burhan, and N. Rahmati, "The impact of sustainability reporting on company performance, " in Journal of Economics, Business, and Accountancy Ventura, vol. 15, no. 2, pp. 257-272, Agustus 2012.

[19] J. Elkington, Cannibals with Forks: The Triple Bottom Line of 21st Century Business. Capstone: Oxford, 1997. 
[20] R. Natalia and J. Tarigan. "The influence of sustainability reporting on the financial performance of public companies in terms of profitability ratio" (in Indonesia), Pengaruh sustainability reporting terhadap kinerja keuangan perusahaan publik dari sisi profitability ratio, in Business Accounting Review, vol. 2, no. 1, 2014.

[21] M. P. Y. Sari, "The influence of financial performance, the size of the company and corporate governance on the disclosure of sustainability report" (in Indonesia), Pengaruh kinerja keuangan, ukuran perusahaan dan corporate governance terhadap pengungkapan sustainability report, thesis, Univ. Diponegoro, Semarang, 2013, unpublished.

[22] R. Shapira, "Corporate philanthropy as signaling and cooptation," Fordham Law Review, vol. 80, pp. 1889-1939, 2012.

[23] Lindstone Jr, and K. Herrick, "Social responsibility - doing good while also making money and protecting owner interests-profit maximization, social responsibility and organizations designed to provide a public benefit", Panel at the Colorado Bar Association's Business Law Institute, October 29, 2015.

[24] Flammer, and Carolline, "Does corporate social responsibility lead to superior financial performance? a regression discontinuity approach", University of Western Ontario, 2013.

[25] K. Bondy, and D. Matten, The Relevance of The Natural Environment for Corporate Social Responsibility Research, in: Hoffman, Andrew; Bansal, Pratima (Eds.) in The Oxford Handbook of Business and the Environment, Oxford (Oxford University Press), 2011.

[26] A. Lako, "The law of sowing and reaping on CSR" (in Indonesia), Hukum tabur-tuai CSR, KONTAN Tabloid, Edition 22, 28 February 2016.

[27] Salem, M. A., Shawtari, F. A., Shamsudin, M. F., \& Hussain, H. I. (2016). The relation between stakeholders' integration and environmental competitiveness. Social Responsibility Journal, 12(4), 755-769.

[28] Okpechi, P. A., Denwigwe, C. P., Asuquo, P. N., Abuo, C., \& Unimna, F. U. (2018). Awareness and Utilization of e-Learning Resources by Trainee Counsellors of Counselling Education in Calabar, Nigeria. International Journal of Educational Technology and Learning, 3(2), 45-51.

[29] Dunst, C. J., Raab, M., Embler, D., \& Roberts, K. (2018). Developing Evidence-Informed Early Childhood Intervention E-Learning Lessons, Performance Checklists and Practice Guides. Journal of Education and e-Learning Research, 5(4), 242-248.

[30] Çelik, I., Çalik, F., Bayraktar, G., \& Bayram, M. (2018). The Investigation on Physical Education Teacher Candidate's Resilience, Tenacity and Motivation Levels. Journal of Education and e-Learning Research, 5(3), 174-178. 